\title{
Features of logistics formation in the Yenisei province
}

\author{
Yuliya Lukinykh ${ }^{1,}$ and Dmitry Kuskashev ${ }^{2}$ \\ ${ }^{1}$ Krasnoyarsk State Pedagogical University named after V.P.Astafiev, 89 Lebedevoy str., 660049, \\ Krasnoyarsk, Russia \\ ${ }^{2}$ Krasnoyarsk State Agrarian University, 117 Lenina str., 600000, Krasnoyarsk, Russia
}

\begin{abstract}
The article deals with the features of logistics formation in the Yenisei province in the late XIX - early XX century. The measures aimed at ensuring food supply and basic necessities to the population, restraining the growth of prices, through the implementation of a mechanism for their regulation are considered. The article analyzes transport logistics as a link in the economic system of the Yenisei province, namely: the transport problems of the period under review are listed, the importance of the construction of the Trans-Siberian railway and the development of navigation are emphasized. The conclusion is made about the prerequisites for the economic development of the Yenisei province in the XXth century.
\end{abstract}

\section{Introduction}

Changes taking place at the present stage in the economic and social life of Russia are directly related to the formation and development of capitalism in Russian society, and this, in turn, causes the need for a deeper understanding of the socio-economic aspect of Russian history. In this regard, the history of Russia in the XIX century occupies a special place, since it was during this period that our country's transition to capitalism took place.

For a deep and objective understanding of the country's development, its economic, social, political, and cultural life, more detailed regional historical works are needed. Study of the nature of Siberia socio-economic development in the XIX century is the most important direction in revealing the general problem of the genesis of capitalism in the history of Russia. Identifying the specifics of the economic and social life of the Yenisei province in the second quarter of the XIX century is an important part of the study of this process [1].

Since logistics is defined as the science of planning, organizing, managing and controlling transportation, warehousing and other material and non-material operations performed in the process of delivering material resources to the enterprise, their consumption in the process of production and delivery of finished products to the consumer in accordance with his needs [2], study of the process of logistics formation in the Yenisei

* Corresponding author: yulla@bk.ru 
province will help to better understand the features of its economic development in the period under review.

\section{Materials and methods}

\subsection{Yenisei province economy}

According to E.V. Bolonkina (2006), during the second quarter of the XIX century, the economy of the Yenisei province was developing in direct dependence on naturalgeographical, demographic and political factors. The process of forming capitalism had contradictory tendencies here. On the one hand, feudal forms of production persisted, and on the other, elements of the capitalist system appeared, complicated by direct dependence on natural resources and their availability [1].

During the study period, the structure of the Yenisei province towns` economy retained its agricultural specifics. So, from the reports of the Yenisei province district towns 'mayors to the governor, in accordance with the circular letter of the Ministry of Internal Affairs, it is clear that the majority of the population of Achinsk, Kansk and Minusinsk were mainly engaged in agriculture and handicrafts, and they belonged to the category of citizens only formally. Reports indicated a low level of industrial and commercial development with the weak rate of trade attributed to the limited purchasing power of the population due to its poverty. At the same time, town heads were confident in the prospects for sustainable growth of town budgets and population [3].

The actual issue of economic activity of the Yenisei province town self-government bodies was the implementation of the competence to ensure food security of municipalities, fight against food speculation, price increases and preventing the development of trends of population impoverishment and social tension.

In order to implement the above tasks, in accordance with the legislation, the town council set monthly fixed prices for basic products: baked bread and meat. Sellers did not have the right to set prices for these products above the rate.

Established by the town council food fixed prices were subject to mandatory approval by the governor and publication in the newspaper "Yenisei provincial Vedomosti" [4].

Additional measures included the systematic adoption of regulations prohibiting the food products sale outside of urban markets. The sale of food in the markets before 12 o'clock in the afternoon was allowed only at retail, after 12 o'clock it was possible to sell and buy food by wholesale. The implementation of these measures was aimed at excluding wholesale purchases of food by speculators, with the aim of their subsequent retail sale at overcharge prices [3].

The problem of chronic budget deficits pushed town governments to address issues of improvement, protection of public order and sanitary and epidemiological safety at the expense of the citizens themselves, by establishing interaction with the emerging civil society, which, however, did not fully comply with the requirements and norms of legislation.

Thus, the Government Senate, by its decision of September 24, 1915, satisfied the complaint of Krasnoyarsk homeowners and cancelled the mandatory resolution of the Krasnoyarsk town council, according to which the initial paving of Voskresenskaya street the central street of the town was assigned to homeowners. The Government Senate reasoned its decision by referring to the town regulation of 1892 , which defined the initial construction of sidewalks and bridges as an integral competence of the town's public administration, while pointing out that the imposition of costs on homeowners is permissible only for the purpose of keeping streets and sidewalks clean and orderly [5]. 
In our opinion, the fact that Krasnoyarsk homeowners filed a complaint with the highest governmental authority about the illegality of the actions of the town government indicates that voters were aware of their rights, ready to defend their interests and thus, corresponding dynamics of legal culture development.

Legally defined by the legislator and authorized by the governor, mandatory resolutions of the town council regulated all spheres of economic and household activities of residents and acted as a factor of socio-legal compensation for the destructive manifestations of municipalities' socio-economic development, in the conditions of the capitalism genesis final stage in the East Siberian region.

The development of the capitalist economy in the Yenisei province by the end of the XIX century brought to the fore the problem of creating a fundamentally new communication system, in accordance with the current level of science and technology development.

In 1892, the first telephone network was established in Krasnoyarsk.

In 1898 , the number of telephone subscribers reached 75 . However, relatively high subscription fee of 75 rubles per year significantly reduced the dynamics of its development [6].

In January 1898 Krasnoyarsk town government with the participation of leading experts formed a commission to develop a plan for electrification of the town. In order to save money, the commission decided to simultaneously install electric lighting not only on the streets of the town, but also in the homes of Krasnoyarsk residents. A relatively low tariff was developed for the installation and use of electric energy for individuals. In addition, the first subscribers were provided with preferential conditions, namely free connection to the town's electricity network and a reduced subscription fee. With these measures, the commission hoped to attract as many citizens as possible and, as a result, achieve maximum cost reduction in the implementation of the program of full electrification of the town.

On April 13, 1912, a power plant built by the town was put into operation in Krasnoyarsk.

In the early autumn of 1913, a water supply system was put into operation in Krasnoyarsk, and on December 27, 1913, a fire-fighting water supply system built by the town began to function [6].

\subsection{Transport issues and options}

Speaking about the development of logistics in the Yenisei province, we can't help mentioning transport as a link in any economic system. Transport is a link between elements of logistics systems, which carries out movement of material resources. Transport is an integral part of production and trade processes.

The development of the province was hindered by an unsolved transport problem. In the late XIX - early XX centuries, the Yenisei province was characterized by weak economic ties between its districts. The region had not developed favorable conditions for entering foreign markets. The reasons were long distances between localities, dense taiga, mountains, and impassability of vessels on the Angara river.

Within the Yenisei province, there were several postal routes that connected economically important localities. The Moscow postal route ran through the entire province from West to East and was of great importance for the grain trade in the region. A significant amount of cargo with bread was sent along it.

In addition to the main highways in the province, there were many country roads, most of them were in a neglected state. In spring and autumn, they became impassable, and remote areas were isolated from each other. Horse-drawn transport had a number of 
disadvantages, such as the high cost of transportation, slow delivery, exhaustion and death of horses, damage of goods, uneven transportation prices, etc.

The opening of shipping lines between Minusinsk and Krasnoyarsk, as well as Krasnoyarsk and Yeniseisk in the early 80's of the XIXth century played an important role in the economic life of the province. The main waterway connecting North and South of the Yenisei province was the Yenisei river.

At the beginning of the XXth century, there was an increase in cargo traffic along the Yenisei, but it was inferior to other Siberian rivers. For example, in 1909, the cargo turnover of the Yenisei river was 10.8 million poods, while the Ob river - 19.5 million poods [7].

Despite the development of shipping, economic ties between the districts of the Yenisei province remained weak, as the transportation of goods was limited, it depended on the season, weather conditions, inability to deliver a large number of goods, and other factors. As noted by T. A. Kiskidosova, due to the imperfection of steamships in technical terms and poor condition of the communication routes, the transportation of goods along the Yenisei did not differ in high speed and was quite expensive to entrepreneurs [8].

In the late XIX - early XX centuries, the Trans-Siberian railway became a powerful factor that significantly revived the Siberian economy. The first proposal to build a railway across Siberia, to the East, to the Pacific ocean, was put forward in 1837. However, the implementation of the project began only in 1891. Construction proceeded rapidly and the first train arrived in Krasnoyarsk on December 6, 1895. At the same time, the first station building, depot, and railway workshops were built. The most important event was the construction of a railway bridge over the Yenisei river.

The railway led to the destruction of the trade monopoly, strengthened the colonization movement, and expanded the capacity of the Siberian market. For 10 years (from 1900 to 1909), there was the following increase in the import of goods to the main stations of the Yenisei province: to Achinsk-5 times, to Krasnoyarsk-3 times, to Kansk - 4.5 times [9].

The construction of the Trans-Siberian railway has led to a noticeable recovery of the economy and a rapid increase in budget revenues of the Yenisei province towns located near the railway [7].

Along the entire length of the railway, railway stations were created, which later grew into new large industrial settlements. Need for a large number of specialists associated with the railway - track guards, switchmen, car couplers, conductors, repair workers, stokers, as well as workers in railway workshops - caused an influx of migrants from European Russia. At the same time, vacancies were filled by local natives - farmers, exiles, representatives of the urban population [9]. During 1893-1911, the population increased by 3 million and reached 9.4 million people [7].

The central point of the Central Siberian railway was Krasnoyarsk. The largest enterprises of Siberia at that time were created in the town - depots and main railway workshops consisting of carriage, assembly, electro-mechanical and turning workshops. In 1898 , they already employ 2,000 workers [9].

In the period from 1895 to 1903 , Krasnoyarsk's budget revenues increased by more than 2 times. The increase in town revenues in Minusinsk was 30\%, Kansk-60\%, and Achinsk-4\%. Town revenues of Yeniseisk over the past period, on the contrary, decreased slightly by $4.5 \%$.

In 1903, the budgets of all the province towns with the exception of Achinsk, were drawn up with a surplus, i.e. with an excess of the revenue over the expenditure part [9].

Radical changes in the economy of Siberian towns led to a shift in the centers of economic life. Old Siberian towns such as Tyumen, Tobolsk and Irkutsk have largely lost their significance. New towns came to the fore - Omsk, Krasnoyarsk, Novonikolaevsk 
(Novosibirsk at present), etc., which, thanks to the construction of the Trans-Siberian railway, began to develop rapidly.

The rapid development of Krasnoyarsk began with the appearance of the railway. Thanks to the Trans-Siberian railway, the regional center quickly turned into an industrial, scientific and administrative one [1].

\section{Conclusion}

At the beginning of the XX century, the Yenisei province remained a sparsely populated and poorly developed region of the Russian Empire. More than half of the population were farmers. Agriculture remained the most important economic activity in the province. Industry was poorly developed, in fact, it did not get out of the stage of handicraft production.

Social and political life in the province did not have the same scale as in central Russia. This is due to the remoteness of the region from the centers of economic and political development, weak development of industry in the province, and the fact that the population was mainly peasant [1].

The state of the road transport system had a direct impact on the development of trade in the Yenisei province. The lack of well-designed wheel roads inside and outside the region led to the restriction of economic ties between individual localities. Waterways were seasonal and could not adequately meet the needs of entrepreneurs. Construction work to improve local transport infrastructure was slow due to inconsistent government policies, bureaucracy, lack of funds, and other factors [8].

But the Yenisei province entered the XXth century, having prerequisites for economic development. The Trans-Siberian railway, migrants who were developing new areas of the region, development of the gold industry, etc. allowed ones to count on the acceleration of the economic and socio-political development of the territory [10].

\section{References}

1. E.V. Bolonkina, Socio-economic development of the Yenisei province in the second quarter of the XIX century (2006) https://www.dissercat.com/content/sotsialnoekonomicheskoe-razvitie-eniseiskoi-gubernii-vo-vtoroi-chetverti-xix-v

2. O.N. Ukasheva, Yu.V. Lukinykh, Problems of modern transport logistics, Proc. Int. Conf. on Logistics, Krasnoyarsk, KrasSAU, 555-558 (2015)

3. M.V. Konstantinova, Grain trade of the Yenisei province in the middle of the XIXbeginning of the XX century, Krasnoyarsk: KSTEI (2010)

4. V.I. Nemchinov, City self-government under the current Russian legislation. City regulations June 11, 1892 with the latest additions and changes to the Continuations of 1906, 1908, 1909 and 1910, with appendices to the "City regulations", the most important explanations of the governing Senate and extracts from other laws relating to the" City regulations" 197-201 (1912)

5. V.I. Fedorova, Development of the transport network of the Yenisei province in the second half of the XIX-early XX century, Economic Development of Siberia, Materials of the Siberian Historical Forum, Krasnoyarsk, Resonance, 39-43 (2016) 
6. V. I. Fedorova, The standard of living of the agricultural population of the Yenisei province in the second half of the XIX century, Bulletin of the Krasnoyarsk State Pedagogical University named after V.P. Astafiev 4, 367 - 372 (2012)

7. Trans-Siberian railway, https:/www.kraskompas.ru/nash-gorod/istoriya/istzametki/item/1102-transsibirskaya-magistral.html

8. T.A. Kiskidosova, Transport infrastructure of the Yenisei province and its influence on the development of trade in late XIX - early XX century, http://www.history.nsc.ru/website/historyinstitute/var/custom/File/1RNMK/016 Kiskidosova.pdf

9. V.V. Chernyshov, Beginning of Trans-Siberian railway construction (1891) http://xn---7sbbimrdkb3alvdfgd8eufwc.xn--p1ai/gosudarstvennyi-arkh/news/pamyatnye-daty/57

10. T.I. Miroshnikova, Yenisei province on the eve of the First world war, http://xn---7sbbimrdkb3alvdfgd8eufwc.xn--p1ai/gosudarstvennyi-arkh/users/articles/212 